Stefan G. Holz

\title{
The Onus Scaccarii Rolls Under Edward I (1272-1307)
}

The main task of royal financial administration was to provide the king with (monetary) resources. While the exchequer at Westminster collected the revenue of the realm, the wardrobe, as the itinerant financial department of the royal household, provided the king directly with cash. To fulfil its task, the wardrobe received cash from a variety of sources. The treasury (lower exchequer) was the main supply of cash for the wardrobe. However, not all of this money was paid to the wardrobe directly. Rather, creditors of the king received large amounts of cash from the treasury in the name of the wardrobe and its officials. To keep track of the cash flow, both institutions-the exchequer and the wardrobe-had to fall back on written records. ${ }^{1}$ This written communication between the exchequer and the wardrobe lies at the centre of this paper. The onus Scaccarii rolls are the key source of this inter-institutional communication under Edward I. ${ }^{2}$ Drawn up in the treasury, the onus rolls kept the ward-

1 The exchequer also received information about cash flow from the chancery in form of the originalia rolls. They are a copy of the fine rolls on which the scribes in the chancery noted the fees paid to the chancery for the expedition of royal charters (see for the originalia rolls Kypta 2014, 234-235; Dryburgh 2015; Dryburgh [s. d.]).

2 The name onus Scaccarii comes from the two Latin nouns: onus meaning 'load' or 'burden', and scaccarium meaning 'chessboard'-the denomination of the accounting cloth of the exchequer, from which the financial institution draws its name. Therefore, the onus Scaccarii rolls are the rolls of the monetary burden of the exchequer. Contemporaries sometimes also called them onus Garderobe (see footnotes 22, 33, 35). As these rolls are called onus Scaccarii in archival finding aids (i. e. List of Documents Relating to the Household and Wardrobe 1964, 13), this denomination is used throughout the article. Scholars have not yet studied the onus rolls in any detail. They are only mentioned in some works (i. e. Young 1840, 249; Tout 1920-1933, vol.1, 22, 236 [also for Edward II]; C. Johnson 1923, 57, 59; J. Johnson 1929, 81 [for Edward II]; Steel 1929, 501; Barratt 2005, 37). The earliest surviving onus rolls are from the later years of Edward I's reign. It is most likely that the rolls were in use before, but did not survive. Not only for the onus rolls but also for most other wardrobe related records, the later years of Edward I are a true goldmine. The abundance of records from the mid-1290s onward is no coincidence. The turbulent political and financial years from the war with France (from 1294) and the war with Scotland (from 1296) led to a wave of records. They survived because of unsettled debts and accounts, which had to be resolved after Edward's death. Therefore, these records served as a written

This publication originated in the Collaborative Research Centre 933 "Material Text Cultures. Materiality and Presence of Writing in Non-Typographic Societies" (subproject B10 "Rolls for the King"). The CRC 933 is funded by the German Research Foundation (DFG). I would like to thank Paul Dryburgh (Kew), Jörg Peltzer and Maree Shirota (both Heidelberg) for feedback on my paper. I would also like to thank all members of staff of the consulted archives and libraries, in particular The National Archives, Kew. All descriptions and transcriptions of manuscripts have been executed in accordance with Guyotjeannin/Vielliard 2014².

Ә Open Access. () 2019 Stefan G. Holz, published by De Gruyter. (c) BY-NC-ND This work is licensed under the Creative Commons Attribution-NonCommercial-NoDerivatives 4.0 License.

https://doi.org/10.1515/9783110645125-007 
robe informed about all the payments the treasury made to or on behalf of the royal household. The wardrobe clerks used the onus rolls to compare them with their own records and compile a final account for audit with the upper exchequer. By examining the process of production and use of the onus rolls, we can grasp the different steps of compiling accounts in both financial institutions. Furthermore, the onus rolls can open a window to the ways records were used in the exchequer and the wardrobe. With few exceptions, the exchequer almost exclusively used rolls for its record keeping. ${ }^{3}$ The wardrobe, however, started to use codices for its accounts alongside rolls from the reign of Edward I onwards. Through an artefact biography of the onus rolls, focussing on their materiality and praxeology, we can get a closer understanding of the use of written records in general, and in particular the choice of the form (roll or codex) in different administrative contexts.

The paper addresses the main questions in four parts. The first chapter discusses the context and function of the onus rolls. Having set the background, the second section will turn to the question of how the onus rolls were compiled in the exchequer. The third part deals with the use of the rolls in the wardrobe. Finally, the fourth brings together the different threads, asking: why were rolls and why codices used in the financial institutions of royal government under Edward I?

\section{Context and function of the onus rolls}

The exchequer collected the revenue of the realm, mainly through the officials (sheriffs) of the local administrative districts (counties). The treasury forwarded the collected cash from the counties after assay and audit to the wardrobe for the king's needs. ${ }^{4}$ Particularly in times of war, when the king constantly needed liquid assets to finance his campaigns, sending money from the exchequer in Westminster to the king, who could be as far away as Scotland or France, was often too slow and inflexible. Therefore, the household officers attempted to resolve this issue through two main ways. When cash from the exchequer was depleted and the king was out of reach for an immediate resupply from the treasury, the officers of the wardrobe acquired the

memory for the later accounting processes under Edward II and Edward III (for this point see also C. Johnson 1923, 53; Prestwich 1997, 105-106). We owe their survival, therefore, to the war-dominated years (1294-1307) of Edward I's reign (Germ. Überlieferungschance). But the wars of the king did not only affect the survival of administrative documents but also their physical size. The overall size of exchequer rolls, particularly the memoranda rolls, as well as legal rolls expanded greatly in the 1290s. 3 See Cassidy in this volume.

4 For the financial relation of the wardrobe and the exchequer and the documentary procedures around it, see J. Johnson 1929, 77-84; and B. Lyon/M. Lyon/Lucas 1983, xxxvi-xxxvii. Johnson writes about the reign of Edward II. However, the administrative procedures did not change much from Edward I to his son. 
income of local officials. Such local officials and other creditors had two options for reimbursement: either the king sent a writ of payment (breve de liberate) to the exchequer for a payment to the creditor to be made, ${ }^{5}$ or the creditor received a bill of debenture (billa) from an official of the king, with which he could collect the money from the exchequer or the wardrobe ${ }^{6}$. The local officials, whose income was lowered through the credit to the king, would have to pay less at the end of their annual audit with the exchequer. The king's chancery wrote a writ of allowance (breve de allocate) to the exchequer, informing it that the local official's account at the exchequer should be reduced, because he paid money for the needs of the king and his administration. ${ }^{7}$ The lower exchequer compiled records in order to keep track of the many payments made by the exchequer directly to the wardrobe and to creditors of the king. The receipt rolls (E 401, rotulus magne recepte) recorded all money paid into the treasury during the accounting period. Often, the receipt rolls did not record real cash receipts, but instead payments made by local officials to the royal wardrobe and its officials. ${ }^{8}$ These transactions were noted on the receipt rolls, since the local officials should have delivered the cash to the treasury in Westminster. ${ }^{9}$ The second main set of rolls in the treasury were the issue rolls (E 403, rotulus exitum). They record all expenditure made out of the treasury in the course of an accounting period..$^{10}$ Both sets of rolls were drawn up twice a year, in triplicate, according to the two main auditing periods: Easter to

5 For a typical writ of payment during Edward's reign: Kew, TNA, C 47/35/15, no. 12 (1285, 18 June.Westminster).

6 See e. g. Kew, TNA, E 101/11/20, no. 25 (1304, 18 August.-Berwick-upon-Tweed).

7 These writs of allowance were written in the chancery after the king ordered them through a warrant of issue. A typical example can be found in: Kew, TNA, C 81/1684A/47 (26 Edward I, 1297-1298, calendared in: Bain 1881-1888, vol.2, no. 978, 250). For a writ of allowance from the keeper of the wardrobe: Kew, TNA, C 81/1328/18 (1301, 29 October.-London).

8 These payments are marked in the receipt rolls with a marginal entry on the right hand side, stating the designator of the payment, either wardrobe or a person, and sometimes the proof of payment, see e. g. Kew, TNA, E 401/154, m. 2: Somerset': Philippo de Guerdon' 676£ pro totidem denariis receptis de $G$ ' de Bere et H' de London', collectoribus $12^{e}$ in comitatu Somersetensis. Garderoba. Duodecim, m. 3: Sutht': Willelmo Russel, custode Insule Vecte, $148 £ 16$ s. 2 d. de remanenti compoti sui. Sandal', m.7: Bed' Buk': Waltero de Molesworth, vicecomite, $10 £$ de firma comitatum. Garderoba. Eodem $8 £$ pro eodem. Garderoba per breve clausum de privato sigillo.

9 These payments were annotated with 'wardrobe' and sometimes the proof of payment was given: e. g. Kew, TNA, E 401/151: 1: Gloucestr': Waltero de Bello Campo, custode castri Gloucestrie, 11 £ de firma sua.-Garderoba, Kew, TNA, E 401/153, m. 1: Essexia: Waltero de Reynes, custode terre abbatisse de Cadamo, 60 £ de exitu ballie sue pro Waltero de Fferstede.-Garderoba per unam litteram.

10 There are two types of issue rolls. A detailed and an abbreviated version. While the first gives all the individual payments, the latter only states the main liberations of the treasury. These two types were also distinguished by the contemporaries of Edward I's administration. The abbreviated version was called roll of spendings (e. g. Kew, TNA, E 403/113: Rotulus exitum in termino sancti Michaelis, anno regni regis Edwardi tricesimo finiente. Anno 30). On the other hand, the detailed issue roll did not bear a main title on the recto side, most of the time, but only a dorse title naming it the membrane of rememberings (e. g. Kew, TNA, E 403/111, m. ${ }^{\mathrm{d}}$ : Pellis memorandorum de termino Pasche, anno regni 
Michaelmas and Michaelmas to Easter. Internally, the rolls are further divided into the four accounting terms: Michaelmas, Hilary, Easter and Trinity. Both sets of rolls were crucial for the auditing of the wardrobe with the exchequer.

From the reign of Henry III, the wardrobe's two major officials, the keeper or treasurer of the wardrobe (custos/thesaurarius) and the controller of the wardrobe (contrarotularius), had to audit wardrobe accounts at the exchequer. The auditing process was required for two reasons: to keep track of and check state finances, and more importantly, to hold officials to account. ${ }^{11}$ The auditing sessions of the wardrobe were quite different from the ones of the sheriffs. While the latter had to come to Westminster twice a year-at Easter for first review of accounts and payments and at Michaelmas for the final auditing-the wardrobe, as the king's private treasury, was not under direct authority of the exchequer. Therefore, auditing, for most of the thirteenth century, did not take place yearly but at irregular intervals. ${ }^{12}$ Despite the lack of systematized auditing periods, the wardrobe had to render accounts containing detailed information about income and expenditure at the exchequer eventually every few years. Hence, the clerks of the wardrobe had to keep preliminary records and memoranda themselves. Detailed information about the money paid out by the treasury to creditors of the wardrobe had to come from the exchequer itself, as the clerks in Westminster were the only ones recording the details of these payments. The institutionalisation of the exchequer from the royal household in the twelfth century forced the officials to develop intermediary documents that enabled a written communication between the institutions. The onus rolls, therefore, connect the non-itinerant exchequer and the itinerant wardrobe as an intermediary record, sending information about payments from one administrative institution to another. ${ }^{13}$ The materiality of the onus rolls, in particular their format, suggest that they were sent after the two main accounting intervals, Easter and Michaelmas, from the exchequer to the ward-

regis Edwardi, filii regis Henrici, tricesimo, tempore Willelmi, Coventrensi et Lichesfeldensi episcopi, thesaurarii. Anno 30).

11 This function of accounts does not only hold true for England, but also the Continent. While Mersiowsky 2007 centres the function of medieval accounts around the accountability of the official who rendered the account. Arlinghaus 2006, for example, additionally recognises the financial purpose of accounts. Most recently, for England in particular, Sabapathy 2014 stressed the importance of accountability for the production of written records. Nevertheless, Sabapathy acknowledges an important step forward in the way accounts were used under Edward I, when counterbalances were introduced (see Sabapathy 2014, 83).

12 For the various reasons regarding irregular accounting periods between the exchequer and the wardrobe in the reign of Henry III: Wild 2012, xvii-xx, xxxvii-xxxviii. From 1258 onwards, the accounting between the two financial centres were done on a regular basis. From 1299/1300 until the death of Edward I in 1307, the auditing sessions were not held until early in the 1320s when Edward II began reviewing some of the later accounts of his father (C. Johnson 1923, 53-54; Prestwich 1988, 144-145). 13 In this respect, they are related to the originalia rolls, another intermediary record, which transmitted information about fines for royal grants from the chancery to the exchequer, see footnote 1 . 
robe. The wardrobe clerks then used the onus rolls to compare the money spent by the treasury with their own lists and accounts. This could ensure that outstanding debts and credits could be crossed out in the wardrobe's accounts. Afterwards, the wardrobe clerks used the onus rolls to compile the detailed receipt section in the wardrobe account books, which would then be sent back to the exchequer for auditing.

\section{Writing the onus rolls in the exchequer}

An onus roll was created when payments were made from the treasury to or on behalf of the wardrobe. The king or one of his higher officials ordered the chancery to issue a writ of payment (breve de liberate) through a warrant of issue. ${ }^{14}$ The chancery sent the writs of payment to the treasury, after enrolling them on the chancery's liberate roll (C 62, liberate et allocate).${ }^{15}$ At the exchequer, the writ was enrolled on the exchequer's liberate rolls (E 403, brevia persoluta) to keep track and have proof of incoming payment orders. ${ }^{16}$ There were two different sets of writs of payment. The first was one for a smaller amount of money, paid directly to the keeper of the wardrobe. The second type could frequently encompass up to $£ 20,000 .{ }^{17}$ Since the treasury did not have such large sums at its disposal, the requested amount was disbursed over the course of many weeks and months in a multitude of payments (liberationes). To keep track of all these payments, the treasury clerks kept memoranda, leading to the compilation of the issue rolls. When compared with modern accounting methods, the system of money disbursed by the treasury in the name of the wardrobe resembles a petty cash system. The wardrobe ordered cash in advance through the writs of payments. The treasury forwarded the cash most often to local officials or individual creditors who ei-

14 See e. g., Kew, TNA, C 81/1668/11 (1303, 13 January.-Odiham, calendared in: Bain 1881-1888, vol. 2, no. 1387, 355).

15 The chancery's liberate roll of the reign of Edward I were 'chancery style' rolls with only a left margin for the name of the beneficiary of the writ of payment. For an enrolled writ of payment: Kew, TNA, C 62/77, m. 1: Pro Johanne de Drokenesford: Regis thesaurio et camerariis suis salutem. Liberate de thesauro nostro dilecto clerico nostro, Johanni de Drokenesford, custodi Garderobe nostre, decem milia libra ad expensas Hospicii nostri, inde faciendas testimonio regis, apud Rypon', 21 die novembris per billam de Garderoba.

16 For an enrolled writ of payment of the wardrobe: Kew, TNA, E 403/1280: Johannes de Drokenefford, custos Garderobe regis: Edwardus Dei gratia et cetera thesauraris et camerarius suis salutem. Liberate de Thesauro nostro dilecto clerico nostro Johanni de Drokenefford, custodis Garderobe nostre, 20,000 marcas ad expensum Hospicii nostri, inde factis. Teste me ipso apud villam Sancti Johannis de Pertz, $15^{\circ}$ die julii, anno regni nostri tricesimo primo: Summa 20,000 marce.

$17 \mathrm{E}$. g. some of the writs of payment for the keeper of the wardrobe enrolled on the exchequer's liberate roll from the later years of Edward's reign: Kew, TNA, E 403/1278 (Easter 1302: £20,000), E 403/1279 (Michaelmas 1302: £20, 000), E 403/1280 (Michaelmas 1303: 20,000 marks), E 403/1284 (Michaelmas 1304: £20,000), E 403/1286 (Easter 1305: £20,000), E 403/1288 (Michaelmas 1305: £20,000). 
ther paid for the king and his household in advance or were not paid by the wardrobe for his services immediately. When the pre-ordered amount of money from the initial writ of payment was reached, a new writ had to be produced.

The wardrobe's final accounts contain two sections: one for receipts and another one for expenses. ${ }^{18}$ While the expenditure of the final accounts under Edward I had more than a dozen sub-sections, the receipt was only split into two: the money forwarded by the treasury (recepta de Scaccario, liberationes de Scaccario), and all other receipts (recepte forinsece). ${ }^{19}$ A review of the account books of the wardrobe reveals that the payments of the treasury constitute the main source of income of the royal household. In the later years of the reign of Edward I, the treasury payments have a share of $75 \% .^{20}$ Given the importance of the payments of the treasury, detailed accounting for these receipts in the wardrobe was necessary. In order for the wardrobe to render correct accounts of their income, the exchequer had to provide comprehensive information about all payments made throughout the two accounting periods. The onus rolls fulfilled that purpose.

The onus rolls are a partial compilation of the issue rolls. ${ }^{21}$ At the end of the accounting term, an exchequer clerk would copy and extract all relevant parts of the issue rolls about payments for the wardrobe onto a new onus roll. ${ }^{22}$ Often, the onus rolls start with a heading, stating the accounting period as well as the regnal year, in most

18 E. g. the final wardrobe account rolls compiled at the exchequer: Kew, TNA, E 101/364/14, m.1: Recepta [...] Expensa [both are headings in the left margin].

19 For the receipt sections: London, The British Library, Add. Ms. 7966A: First section: four exchequer liberations: liberationes de Scaccario (fol.1-11 ${ }^{\nu}$ ), second: foreign income: recepta forinseca, such as perquisites of merchants (fol.13-14v), sale of stock (fol.14v), siege of Bayonne (fol.15), great seal (fol.15v), sale of jewels (fol.15v), monetary restitution (fol.15v), sale of corn and other goods in the counties (fol.16), sale of victuals (fol.16-17v), sale of stock from the queen's household and other income (fol.17v), tax (fol.18). For the expense sections of the wardrobe books of Edward I: B. Byerly/C. Byerly 1977, xi-xv.

20 This percentage is for the available years of the last decade of Edward's reign. The data is based on Tout's calculation (Tout 1920-1933, vol.1, 80-83). If Tout does not provide data, I used data from manuscripts where possible: 1. 1295-1296: 61 \%, 2. 1296-1297: 71\%, 3. 1287-1298: 77\%, 4. 1299/1300: 84\%, 5. 1300-1301: 82\%, 6. 1301-1302: 61\% (Kew, TNA, E 101/360/25, m. 6), 7. 1302-1303: 83\% (Kew, TNA, E 101/364/14, m. 1), 8. 1305-1306: 78\%.

21 The onus rolls might have been compiled from the issue rolls directly, or from a draft of the issue roll. The direct connection between the issue and onus roll is not only evident in the almost identical structure of both records, but also in some references in the onus rolls to the issue roll, see e. g. Kew, TNA, E 101/364/24, m. 1: Eidem eodem die $113 £ 13 \mathrm{~s} .11 \frac{1}{2}$ d. in quatuor talliis factis Johanni de Wemgrave, vicecomiti Essex' et Hertford', sicut patet in rotulo magne recepte presentis die per unam litteram dicti custodi patentem, cuius data est apud Eboracum $17^{\circ}$ die aprilis, anno regni regis Edwardi $31^{\circ}$, penes camerarium residentum liberantur eundem. However, the onus rolls are not a verbatim copy as J. Henry Johnson 1929, 81 has stated.

22 Not many traces of the scribes themselves can be found on the rolls. An exception is e. g. Kew, TNA, E 101/361/12, m. 16 ': Scriptus manu J', clerico domini R' de Sch'. 
cases even offering a contemporary designation for the roll itself. ${ }^{23}$ Every accounting period begins with the enrolled writ of payment, constituting the legal framework for all expenditures of the treasury. These writ entries follow a formula: starting with the name of the keeper of the wardrobe as the beneficiary of the payments; followed by an authorizing document (writ of payment) with the total sum of payment as well as the date and location of issue. While the exact wording may differ slightly, all writ entries include the same elements. ${ }^{24}$ The individual payment entries comprise the date of payment, followed by the sum, the recipient's name of the payment and the purpose, often with the written proof presented at the treasury. If more than one payment occurred on one day, which was very frequent, the following entries begin with the phrasing to the same at the same day (eidem eodem die). Even though the onus rolls are text block accounts, the exchequer scribes tried in many cases to separate individual entries from one another. They mainly used three methods to achieve this: one, with a pilcrow (Tा or cc); two, by separating two entries with a space; three, by writing the letter of the first word, mostly $E$ for eidem, in a larger font. The scribes used this type of separation and formula in many other records. The best example of this is found on the pipe rolls. ${ }^{25}$

To understand the copying and compilation process from the issue rolls to the onus rolls, sections of the Michaelmas 30 Edward I (1301/2) and the corresponding onus roll are compared. The lengthy table is necessary to grasp all the minor changes the scribe made while extracting and copying the issue rolls. These minor details reveal how the scribes of the treasury worked.

23 See Kew, TNA, E 101/355/9, m. 1: In termino sancti Michaelis anno 26 ${ }^{\text {to }}$ finiente; E 101/358/17/11, m. 1: Recepta domini Johannis de Drokenesford, Michaelis anno 35 ${ }^{\text {to }}$; E 101/361/12, $\mathrm{m}$ 7: In termino Pasche anno 30 E 101/366/24, m. 1: Onus Garderobe de anno tricesimo tertio, videlicet: de termino sancti Michaelis anno $32^{\circ}$ incipiente 33; E 101/368/26, m. 1: Onus Garderobe de anno regis Edwardi 34to ; E 101/684/4, m. 1: Onus Scaccarii termino Pasche anno $28^{\circ}$. In some cases, such as the latter three examples, the heading was probably not written down by the exchequer clerk but the wardrobe's.

24 For sum-recipient-reason-proof-date: see e. g. Kew, TNA, E 101/366/24, m. 2: 20 marce liberavit Huetto de la Ruele, valletto regine, de dono domini regis eunti ad partes suos per preceptorium Thesaurarii, $13^{\circ}$ die januarii. For sum-date-proof-recipient-reason: see e. g. Kew, TNA, E 101/366/24, m. 1: $11 € 8$ s. liberavit eidem tertio die decembris in una tallia, facta Laur' de Preston', de firma de Gretton' per unam litteram dicti custodis patentem, cuius data est apud Dunolm', 20 die septembris, anno $32^{\circ}$, penes camerarium.

25 See for the construction and layout of the pipe rolls: Kypta 2014, 51-63. 
[Issue roll, Kew, TNA, E 403/111, m. $1^{\mathrm{a}}$, beginning of first section]

[1] Domino Johanni de Drokenesford, custodi Garderobe regis, super breve suum de liberate continente 20,000 £, cuius data est apud Lynliscu, $21^{\circ}$ die novembris, anno regis Edwardi $30^{\circ}$.

[2] 2 die maii: $89 £ 6 s .6$ d. in una tallia, facta Philippo de Geyton', vicecomite Warrensis et Lincolniensis, de remanenti compoti sui per unam litteram dicti custodis patentem, cuius data est London', nono die aprilis, anno regni regis Edwardi 30, penes et cetera.

$[3, \ldots$, end of first section $]$ Eidem $8^{\circ}$ die maii: $30 €$ in una tallia, facta priori de Hermodesworth', pro taxacione domus sue per unam litteram dicti custodis patentem, cuius data est London' $24^{\text {to }}$ die marcii, anno presenti et cetera.

[4] Eidem eodem die: $296 £ 6$ s. 4 d. in decem tallias, factas Hugoni de Bussey, vicecomite Lincolniensis, quarum una in rotulo magne recepte et nonem in rotulo religiosarum presenti die per unam litteram dicti custodis patentem, cuius data est London, $16^{\circ}$ die aprilis, anno presenti et cetera.

[5] Summa istius panelli: 1,640 £ $12 \mathrm{~s} .2 \mathrm{~d}$. probatur.

[6] Summa omnium liberationum, factarum dicto domino Johanni de Drokenesford, tam in pelle presenti quam in pelle de termino sancti Michaelis proxima, preceptum super breve suum de liberate continente 20,000 £, cuius data est apud Linliscu, 21 die novembris anno regis Edwardi $30^{\circ}$ : $20,147 £ 5$ s. $51 / 2$ d. Et sic persolvitur breve. Et hec ultra summam in dicto brevi continentam: $147 \mathrm{f}$ $5 \mathrm{~s} .51 / 2 d$., de quibus oneratur in proxima brevi suo de liberate in mediate sequentur continente 20,000 £, cuius data est apud Devises, vicesimo die aprilis, anno $30^{\circ}$.
[Onus roll, Kew, TNA, E 101/361/12, m. 7, beginning of first section]

[1] In termino Pasche anno $30^{\circ}$ :

Domino Johanni de Drokenesford, custodi Garderobe regis, super breve suum de liberate continente 20,000 £, cuius data est apud Linlichku, 21 die novembris, anno presenti.

[2] Secundo die maii: $89 £ 6$ s. 6 d. in una tallia, facta Philippo de Gayton', vicecomite Warrensis et Lyncolniensis, de remanenti compoti sui per unam litteram dicti custodis patentem, cuius data est London', 9 die aprilis, anno $30^{\circ}$, penes camerarium residentum liberantur eidem.

[4, ..., end of first section] Eidem 8 die maï: $296 €$ 6s. 4d in 10 talliis, factis Hugoni de Busseye, vicecomite Lincolniensis, quarum una in rotulo magne recepte et 9 in rotulo religiosarum, presenti die per unam litteram dicti custodis patentem, cuius data est London', 15 die aprilis, anno presenti et cetera.

[3] Eidem eodem die: $30 £$ in una tallia, facta priori de Hermodesworth', pro taxacione domus sue per unam litteram dicti custodis patentem, cuius data est London', $24^{\text {to }}$ die marcii, anno presenti et cetera.

[5] Summa a principio termini Pasche usque huc-1,640£ 12 s. 2 d. probatur. 
[7, beginning of second section]

Prime liberationes brevis sequentur:

Domino Johanni de Drokenesford, custodi Garderobe regis, super breve suum de liberate continente 20,000 £, cuius data est apud Devises, $20^{\circ}$ die aprilis, anno $30^{\circ}$.

[8] $147 £ 5 s .51 / 2 d$. de superplusagio predicti brevis immediate precedentis, quas recepit ultra summam, in eodem brevi continente liberabitur eodem $8^{\circ}$ die maii.

[9] Eidem $9^{\circ}$ die maii: 70 £ liberavit domino Waltero de Burdun' in persolutionem $100 \mathrm{f}$, quas debuit recepisse in ultimo medio tempore in $40^{\text {ti }}$ de domino Radulpho de Dalton', que dictus dominus Walterus primus recepit 30 £ per manus Johannis de Cambhou, vicecomitis Northumbrie, sicut patet $4^{\text {to }}$ die maii.

$\left[10, \ldots\right.$, end of second section, m. $\left.1^{\mathrm{a}-\mathrm{b}}\right]$ Eidem $9^{\circ}$ die junii: $3 \mathrm{~s}$. liberavit Williamo de Coshals', clerico, in persolutionem $4 € 13 \mathrm{~s}$. pro 62 petitionibus scribendis de libro, qui vocatur librum de feodis, videlicet pro petitione $18 \mathrm{~d}$.

[11] Summa istius panelli de prime onere istius brevis usque huc: 1,677 £ 2 s. 71/2 d. probatur.
[7, beginning of second section] Domino Johanni de Drokenesford, custodi Garderobe regis, super breve suum de liberate continente 20,000 £, cuius data est apud Devises, 20 die aprilis, anno regni regis Edwardi $30^{\circ}$.

[9] $70 £$ liberavit domino Waltero de Burghdon' in persolutionem centum librarum, quas debuit recepisse in ultimo medio tempore in $40^{\text {ti }}$ de domino Radulpho de Dalton', que dictus dominus Walterus primus recepit $30 £$ per manus Johannis de Cambhou, vicecomitis Northumbrie, sicut patet $4^{\text {to }}$ die maii, liberavit eidem 9 die maii.

$[10, \ldots, m .8$, end of second section $]$ Eidem $9^{\circ}$ die junii: 3 s. liberavit Willelmo de Coshale, clerico, in persolutionem $4^{\text {or }}$ librarum 13 s. pro 62 petitionibus scribendis de libro, qui vocatur liber de feodis, videlicet pro petitione $18 \mathrm{~d}$. Brevis usque huc.

Although at first glance, the section beginnings and ends of the two rolls seem almost identical, some noteworthy differences occur. The first is the altered order of individual entries at the end of the first section (nos. 3 and 4). The scribe switched around the sequence of the last two entries. This is an indicator of an unintended modification, which can occur during the copying process. Other minor differences are mostly connected with the spelling, particularly of place and personal names. Beside these minor differences and unintended alterations, the exchequer copyist actively excluded some information (nos. 6 and 8). This is explicable by the internal exchequer proceedings. When the exchequer received a writ of payment, the clerks kept track of all expenditure, until the initial sum of the writ of payment was exhausted. Since the payments seldom added up to exactly the sum in the writ, a carryover remained, which had to be accounted for with the next writ of payment. These transferral accounting steps were noted on the issue roll for internal exchequer proceedings, but rarely copied onto the onus rolls, as they were not relevant to the accounting of the wardrobe.

The scribes of the exchequer did not have a uniform layout formula for the onus rolls. Each roll consists of multiple parchment membranes. All of the rolls are drawn up in chancery fashion, which means that the membranes are sewn together foot to 
head. ${ }^{26}$ The stitches was executed in multiple ways. The most common is similar to modern sewing seams, such as open and closed seams, or overlapping seams. ${ }^{27}$ In general, the exchequer clerks wrote only on one side of the onus rolls. ${ }^{28}$ The individual membranes could be of varied formats and not align with each other. ${ }^{29}$ A striking example for inconsistent formats within one roll is the onus roll for 30-31 Edward I (13011303) ${ }^{30}$ It is not only the longest roll, covering two regnal years with twenty-seven membranes but also the roll with membranes deviating from one another the most. The width of the membranes fluctuates between $180 \mathrm{~mm}$ and $295 \mathrm{~mm}$; with an average width of around $200 \mathrm{~mm}$. The membranes' lengths could also vary between $195 \mathrm{~mm}$ to $725 \mathrm{~mm}$, while the average length is around $500 \mathrm{~mm}$. With most other onus rolls, there is less variation between the widths of each membrane, whereas the lengths are mostly inconsistent. The scribes tried to use membranes of a certain width and to a lesser extent length within one roll. This is a strong indicator that the scribes actively chose similar membranes for a particular accounting period and altered the format when they started with a new one. A good example is again the onus roll for 30-31 Edward I (1301-1303). After membrane five, the Lent term (Quadragesima) starts with a new membrane width. The same occurs just one membrane later, at the transition of membranes six and seven, when the new Easter term (Pascha) commences. While the break between membranes five and six is not as obvious from a textual standpoint, the change between membrane six and seven is clearer. Membrane six ends with a final sum for all spending of the mid-accounting term (medium tempus) and membrane seven starts with a new heading for the Easter term. ${ }^{31}$ This clear break between the two membranes (six and seven) can be explained with the interval between the accounting terms Michaelmas 1301/2 (m. 1-6) and Easter 1302 (m. 7-11). A similar interval also appears between the issue roll for Michaelmas 1301-1302 (issue roll lost) and Easter 1302 (E 403/111). The exchequer scribe started with a new membrane (m. 12) in a very

26 Rolls in the royal administration of medieval England come mainly in two forms: firstly, the 'chancery style', which in continental Europe is most often defined as a rotulus (Cárcel Ortí 1997², no. 38, 29), and secondly, the 'exchequer style', composed of one- or two-membrane chancery style rotuli, which were sewn together at their heads to form a multi-layered roll (Giele/Peltzer/Trede 2015, 680-681).

27 An example for the latter case is Kew, TNA, E 101/361/12 where membranes 6 and 7, both written at different stages of the exchequer year, are connected with a continuous seam. The same roll also provides an example for the first case: the current seam connecting membranes 4 and 5 is a later addition, as previous stiching holes show.

28 Kew, TNA, E 101/684/4. Additionally, only membrane 3 of E 101/361/12 was inscribed on both sides. 29 See the table of surviving onus rolls in the appendix of this article.

30 Kew, TNA, E 101/361/12.

31 Kew, TNA, E 101/361/12, m. 6: Summa huius medii temporis apud Westmonasterium-4,585£ $9 \mathrm{~s}$. $21 / 2 d$. Summa totalis eius Johannis de Drokenesford presentis pellis super breve suum de liberate continet 20,000 £, cuius datum est apud Linliscu, 21 die novembris, anno presentis-13,575£ 19 s. 111/2 d., m. 7: In termino Pasche anno $30^{\circ}$. In contrast, m. 5 starts with the heading: Solutiones ffacte domino Johanni de Drokenesford, custodi et cetera, apud Westmonasterium in Quadragesima, anno regis Edwardi 30. Membrane 5 ends only with a membrane sum: Summa istius rotuli-1,122 £ 161/2 d. probatur. 
divergent format. Some transitions are not as apparent. The next start of a new accounting period, Easter 1303 (E 403/114), did not change the format of the membranes of the onus roll (m.17-18). ${ }^{32}$ This leads to the conclusion that the exchequer scribe did not send the onus rolls immediately after each accounting period to the wardrobe, but sometimes kept them over multiple accounting periods and sent them together.

Most of the onus rolls are sum- and heading-divided text block accounts. ${ }^{33}$ Even though a general pattern lies behind them, the layout of the onus rolls also changed slightly from accounting period to accounting period. This is largely to do with the scribal habits and the parchment available. In comparison to other more important roll series (such as the pipe, receipt or issue rolls), the format and shape of the membranes and the entire roll did not matter much. The scribes could chose the parchment they used. The headings of the rolls and the individual segments mirror the titles in the issue rolls. They generally refer to the accounting periods of the exchequer and in some cases to the keeper of the wardrobe and the writ of payment. ${ }^{34}$ Most of the time, they were written larger or highlighted. Section sums also helped to structure the text and to calculate the money sent. ${ }^{35}$ Frequently, these section sums were not

32 Furthermore, the exact same ruling of the left margin is a second important indicator that the exchequer scribe continuously used the Michaelmas 1302 onus roll for the Easter 1303 term.

33 The classification of different styles according to their layout has been introduced by Mersiowsky 2000, 337-344.

34 See e. g. Kew, TNA, E 101/355/9, m.1: In termino sancti Michaelis anno $26^{\text {to }}$ incipiente, [...] Item receptum eiusdem domini Johannis in termino sancti Hillarii, m. 3: Liberationes, facte in medio tempore in $40^{a}$ apud Westmonasterium, [...] In termino Pasche anno $27^{\circ}$, m. 6: Item liberationes, facte eidem domino Johanni post festum Sancte Trinitatis, m. 8: Item in medio tempore, m. 9: In termino sancti Michaelis anno $27^{\circ}$ finiente; E 101/366/24, m. 1: Onus Garderobe de anno tricesimo tertio. [later addition by the same hand] Videlicet de termino sancti Michaelis anno $32^{\circ}$ incipiente $33^{\circ}$, [...] Liberationes in medio tempore facte domino Johanni de Drokenesford super breve suum, continente 20,000 £, [...] Liberationes facte domino Johanni apud Westmonasterium post festum Sancti Hillarii super dictum breve suum de liberatione continet 20,000 et cetera, m. 2: Item liberationes facte domino Johanni de Drokenesford, custodi Garderobe regis, in medio tempore post festum sancti Hillarii per breve suum de liberate continete 20,000 £, cuius datum est apud Brustewyk' $21^{\circ}$ die novembris, anno tricesimo secundo, m. 3: Adhuc de onere Garderobe et cetera, videlicet de termino Pasche anno tricesimo tertio. Item liberationes facte domino Johanni de Drokenesford, custodi Garderobe regis, super breve suum de liberatione continet 20,000 E, cuius datum est apud Brustewyk' $21^{\circ}$ die novembris, anno regni regis Eduardis tricesimo secundo, m. 4: Item liberationes facte domino Johanni de Drokenesford, custodi Garderobe regis, post festum Sancti Trinitatis super breve suum de liberate continet 20,000 £, cuius datum est apud Brustewyk $21^{\circ}$ die novembris, anno regni regis Edwardi 32 $2^{\circ}$, [...] Prime liberationes brevis sequentis, $\mathrm{m}$. 5: Item liberationes facte domino Johanni de Drokenesford, custodi Garderobe regis, in medio tempore super breve suum de liberate continet 20,000 E, cuius datum est apud Lewes $26^{\text {to }}$ die junij, anno regni regis Edwardi $33^{\circ}$, [...] Item liberationes facte domino Johanni de Drokenesford, custodi Garderobe regis, super breve suum de liberate, datum est apud Lewes $26^{\text {to }}$ die junii, anno regis Edwardi tricesimo tertio, m. 6: Prime liberationes brevis sequentis.

35 See e. g. Kew, TNA, E 101/366/24, m. 3: Summa totius oneris Johanni de Drokenesford istius termini usque huc-8,726£ $2 \mathrm{~s} .81 \frac{1}{2} \mathrm{~d}$., m. 5: Summa istius panelli et cetera 15,661 £ $11 \mathrm{s.} 61 / 2 \mathrm{~d}$. 
only written larger, but also indented to set them visually apart from the main text. The exchequer accounting periods and sometimes a contemporary title of the roll itself is found on the dorses. ${ }^{36}$ These dorse titles helped to identify the roll in its closed form, as these titles were written either on the last or first membrane. After their compilation in the treasury, the onus rolls were sent to the wardrobe as means of written communication.

\section{Using the onus rolls in the wardrobe}

The wardrobe kept detailed records of receipts during the accounting year. These records had very different forms and formats. We have small rolls, which seem more like drafts, covering only very short periods and recording expenditure as well as receipts. ${ }^{37}$ These rolls might have been used by the scribe as a minute from which to draw a neater record. Early in the reign of Edward I, the wardrobe clerks wrote down well-structured receipt rolls covering the whole accounting year. ${ }^{38}$ Later in the reign,

36 It is yet not clear if these endorsements were written by the exchequer or wardrobe scribes. The last two examples are definitely from a wardrobe scribe: Kew, TNA, E 101/355/9, m. $9^{\mathrm{d}}$ : Recepta Garderobe de onere Scaccarii de anno $27^{\circ}$; E 101/361/12, m. $16^{\mathrm{d}}$ : Onus Garderobe de termino sancti Michaelis anno $30^{\circ}$ finiente, scilicet a $12^{\circ}$ die octobris usque 8 diem decembris, utroque die computatur; E 101/368/26,

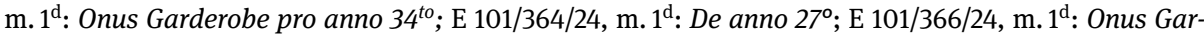
derobe regis a die sancti Edmundi usque festum Pasche [second hand] Onus per Scaccarium de anno $31^{\circ}$ [third hand] Vacant omnes isti rotuli, quod continentur in maioribus rotulis; E 101/366/24, $\mathrm{m} .1^{\mathrm{d}}$ : De anno $33^{\circ}$ [later addition by the same hand] Intratur totum et examinatur; E 101/368/26, m. $1^{\mathrm{d}}$ : Onus Garderobe per Scaccarium de anno $34^{\text {to }}$. [later addition by the same hand] Examinatur et intratur, m. $9^{\mathrm{d}}$ : Onus Garderobe regis de anno tricesimo quarto. [later addition by the same hand] Examinatur; E 101/684/4, $\mathrm{m} .1^{\mathrm{d}}$ : Onus Scaccarii termino Pasche anno $28^{\circ}$.

37 See e. g. Kew, TNA, E 101/357/11, no.3: short roll of receipts and expenses, where the receipt section only has one entry: De Reginaldo le Portor, vicecomite Wygornensis, de exitu ballie sue comitatus in denariis per ipsum solutis pro carriagio venatoris de Ffekenham usque London', anno 27, quam pro frumento et avena provisis per ipsum infra balliam suam predictam ad expensis Hospicii regis ac etiam pro aliis particulis diversis pro rege, anno 29, in una littera sibi facta thesaurarii et camerariorum de Scaccario sub sigillo domini Johannis de Drokenford, cuius data est apud Eboracum, 21 die januaris, anno 30. $-128 £ 16 \mathrm{~s}$. [..., lost text].

38 See. e. g. Kew, TNA, E 101/351/10, m.1: Rotulus recepte denariorum in Garderoba domini Edwardi, illustris regis Anglie, a festo sancti Edmundi regis et martiriis, anno regni predicti regis Edwardi incipiente undecimo usque ad idem festum, anno regni eiusdem regis finiente duodecimo, incipiente tertiodecimo tempore magistri Willelmi de Luda, tunc custodis Garderobe regis, et Thome de Gunneys, contrarotulatoris sui, a predicto festo sancti Edmundi anno $11^{\circ}$ usque festum assumptionis Beate Virginis, anno eodem. Et post idem festum tempore magistri Willelmi de March, contrarotulatoris sui, in eadem Garderobam usque festum sancti Edmundi regis, anno regni eiusdem regis Edwardi finiente duodecimo et incipiente $13^{\circ}$. This receipt roll has a very evident structure. The left margin gives the origin of the received money, while the right margin states the individual entry's sum. Furthermore, every group of receipts ends with a collective sum, indented to the middle of the membrane. The scribe added several 
at least from the mid-1290s, the final receipt rolls of the wardrobe were accompanied by receipt account books. ${ }^{39}$ Additionally, the wardrobe kept cash journals in codices. ${ }^{40}$ The cash journals contained daily preparations of income and expenditure as well as a balance of ready cash at the end of a day.

The wardrobe kept books for their accounting from the late 1270 s. $^{41}$ In the course of Edward's reign, more and more records of the wardrobe were kept in books in addition to or rather than rolls. ${ }^{42}$ At the end of the accounting year, a wardrobe clerk compiled a final account book, which was sent to the upper exchequer in two copies for audit. ${ }^{43}$

The wardrobe clerks used the onus roll in two ways: copying their textual content into the wardrobe's account book receipt section and comparing the entries of the onus roll with their own records. We have to bear in mind, however, that the scribes did not fall back on the wardrobe's own receipt records to compile the exchequer receipt section in the final account book, but relied exclusively on the information conveyed on the onus rolls. To see the similarities between the two records, even though they were written in two different forms-roll and codex-it is vital to compare two similar sections from both records in detail. This does not only reveal similarities, but also shows minor interventions by the wardrobe's scribe. The entries are from 34 Edward I (1305/6).

subtotal sums (see e. g. m. 2: Quarta summa totalis istius rotuli 30,466£17 s. 3 d.), adding up to a final total sum at the end of the roll (m. 2: Summa totalis totius istius rotuli 101,952 $£ 17 \mathrm{~s} .2 \mathrm{~d}$. The same final total sum can be found on $\mathrm{m} \cdot 1^{\mathrm{d}}$ ).

39 See e. g. Manchester, John Rylands Library, Lat. Ms. 230, title on cover: Recepta Garderobe regis Edwardi de anno regni sui vicesimo secondo 22. Recepta anno $22^{\circ}$.

40 The journalia accounts had two columns: the left one for income and the right one for expenditure, e. g. London, The British Library, Add. Ms. 37655, fol. $5^{\mathrm{a}}$ : Die mercuri, $27^{\circ}$ die julij, anno $34^{\text {to }}$ de denariis in Garderoba remanentibus $7 \mathrm{~s}$. 2 d. De Scaccario per manus Nicholai de Chileham et Willelmi de Rikethorn' liberaverunt denaria in Garderoba apud Sherreve Hounton' $400 \mathrm{E}$.

41 The oldest extant fragment of a wardrobe account book dates from 1275-1276 or 1277-1278 (TNA Kew, C 47/3/51/10).

42 The introduction of the codex in the accounting of the wardrobe has not yet been explained. T. F. Tout only recognised the introduction of the codex in the royal wardrobe (Tout 1920-1933, vol.1, 47-48). In general, scholars (e. g. Ramsay 2008, 422) acknowledge their existence, even describing some in detail (B. Byerly/C. Byerly 1977; Parsons 1977, 3-28; B. Byerly/C. Byerly, 1986, i-vi; B. Lyon/M. Lyon 2004, vii-viii) but not explaining them. Only M. C. Prestwich has brought forward the hypothesis, drawing on the research by George Sivery for the financial administrations of Flanders, that Italian accounting might have influenced the wardrobe (Prestwich 1997, 96). Possible origins of the introduction of the codex into the royal wardrobe and their contexts of use will be discussed in my upcoming $\mathrm{PhD}$ thesis at Heidelberg University.

43 Before the 1290s, the wardrobe books were not as well structured. Afterwards they had a first section for receipts and a second larger section for expenses. See the editions of early Edwardian wardrobe books Records of the Wardrobe and Household, eds. B. Byerly and C. Byerly; The Court and Household of Eleanor of Castile in 1290, ed. Parsons; Records of the Wardrobe and Household, eds. B. Byerly and C. Byerly and for the late Edwardian wardrobe books Liber quotidianus contrarotulatoris garderobae, ed. Topham; The Wardrobe Book of 1296-1297, eds. B Lyon and M. Lyon (only a partial edition). 
[Onus roll, Kew, TNA, E 101/368/26, m.1, beginning of the roll]

[1] Domino Johanni de Drokenesford, custodi Garderobe regis, super breve suum de liberate continente 20,000 £, cuius data est apud La Thele, 21 die augusti, anno $34^{\text {to }}$.

[2] $46 £ 1$ marca liberavit domino Waltero Reginaldi, custodi Garderobe domini principis Wallie, per manus Thome de Petvenes, die mercurii, $24^{\text {to }}$ die novembris, super expensis dicti domini principis per preceptum J' de Dirk' tenentur [..., unreadable].

[3] Eidem die sabbati, 27to die novembris: $13 €$ liberavit magistro Johanni de Claxton' super expensis dominorum [Thome et Edmundi], filiorum regis, per preceptum dicti Johannis et cetera.

$[4, \ldots$, end of section and beginning of new section] Eidem eodem die: $20 £$ liberavit Tome Brun, puletario regis, per manus Ade Brun super officio suo per breve sub privato sigillo regis continente $200 £$, cuius data est apud Kynemerefford, 6 die decembris et cetera.

[5] Item liberationes facte eidem in medio tempore post festum sancte Lucie super dictum breve.

[6] Domino Johanni de Drokenesford et cetera super dictum breve de 20,000 £, cuius data est et cetera.

[7] 13 £ liberavit magistro Johanni de Claxton’, die lune, 13 die decembris, super expensis dominorum Thome et Edmundi, filiorum regis.

$[8, \ldots, \mathrm{m} .3$, end of first writ of payment and beginning of second one]

Eidem 17 die maii: $4,798 £ 161 / 2 \mathrm{~s}$. in una tallia, facta Berto de Ffriscobaldi et sociis suis mercatorum de societate mercatorum de societate Friscobaldorum de Florentina, collectorum custume lanarum, coriorum et pellium lannarum de exitus eiusdem custumen in Anglie et Hibernie, sicut
[Final wardrobe account book, Kew, TNA, E 101/ $369 / 11$, fol.1, beginning of receipt section]

[1] De domino Waltero de Langeton, thesaurario et camerariis de Scaccario, de Thesauro regis ad expensum Hospicii eiusdem, inde faciendum super unum breve de liberate continente 20,000 £, cuius data est apud La Thele, $21^{\circ}$ die novembris, anno $34^{\text {to }}$, per manus diversorum infra annum presentem prout patet inferius et videlicet:

[2] Per manus domini Walteri Reginaldi, recipienti denariis ad expensum Hospicii domini principis Wallie, inde faciendum $24^{\text {to }}$ die novembris $46 € 13 \mathrm{~s} .4 \mathrm{~d}$.

[3] Per manus magistri Johannis de Claxton' super expensis Hospicii dominorum Thome et Edmundi, filiorum regis, 27 die novembris $14 \mathrm{€}$.

$\left[4, \ldots\right.$, fol. $\left.1^{\mathrm{v}}\right]$ Per manus Thome Brun, puletario re gis, super officio suo per breve sub privato sigillo regis continente $200 £$, cuius data est apud Kynemerefford', $6^{\text {to }}$ die decembris et cetera, eodem die $20 €$.

[7] Per manus magistro Johanni de Claxton' super expensis Hospicii dominorum Thome et Edmundi, filiorum regis, $13^{\circ}$ die decembris $14 \mathrm{€}$.

$\left[8, \ldots\right.$, fol. $4^{\mathrm{v}}$, end of first writ of payment, begin ning of second one]

Per manus Bertini de Ffrisconbaud' et sociorum suorum mercatorum de societate Ffrisconibaldorum de Florentia, collectorum custume in Anglia, in una tallia, eisdem facta, pro tot denariis, quos idem mercatores solverunt in Curia Romana et alibi pro negotiis regis, 17 die maii: 4,798 £161/2s. 
patet in rotulo magne recepte presenti die, pro tot denariis, quos iidem mercatores solverunt in Curia Romana et alibi pro negotiis regis, unde liberaverunt particulas eiusdem Johannis de Drokenesford in Garderoba dicti regis.

[9a, m. 4] Liberationes facte eidem super breve de liberate continente 20,000 £, cuius data est apud Ffarnham, $16^{\text {to }}$ die maii, anno $34^{\text {to }}$ :

[10] Domino Johanni de Drokenefford, custodi Garderobe regis, super breve suum de liberate continente 20,000 £, cuius data est apud Ffarnham, $16^{\text {to }}$ die maii, anno regni regis Edwardi $34^{\text {to }}$.

[11] 1,029£ 11s. 11/2d. liberavit eisdem, $17^{\circ}$ die maii, in una tallia, facta Berti de Ffriscobaldi et sociis suis mercatorum de societate Friscobaldorum de Florentia, collectorum custume lanarum, coriorum et pellium lanarum [de exitus eiusdem custumen] in Anglie et Hibernie, sicut patet in rotulo magne recepte presenti die, per preceptum Thesaurarii pro tot denariis, quos idem mercatores solverunt in Curia Romana et alibi pro negociis regis, unde liberaverunt particulas eidem Johanni de Drokenefford, [custodi Gardeorbe] regis . [9b] Summa totalis solute super isto breve de liberate continente 20,000 £, cuius data est apud La Thele, $21^{\circ}$ die novembris, anno presenti $34^{\text {to }}$ : 20,000 .

[10] De eisdem thesaurario et camerario de Thesauro regis ad expensum Hospicii ipsius regis, inde faciendum super unum breve de liberate continente 20,000 £, cuius data est apud Ffarnham, $16^{\circ}$ die maii, anno $34^{\text {to }}$ :

[11] Per manus Berti de Ffriscunibaldi et sociorum suorum mercatorum de societate Ffriscunibaldorum de Fflorentia, collectorum custume lanarum, coriorum et pellum lanarum in Anglie et Hybernie in una tallia, facte eisdem mercatoribus, pro tot denariis, quos idem mercatores solverunt in Curia Romana et alibi pro negotiis regis, 17 die maii: 1,029 £ $11 \mathrm{s.} 11 / 2 \mathrm{~d}$.

The copying process in the wardrobe changed entries. Some were not copied at all. Mostly, the omitted entries relate to the internal accounting terms of the exchequer and had therefore no value for the final records of the wardrobe. The clerk slightly shortened most of the entries. Information, which for the scribe did not deem necessary, was cut out. In general, the scribal interventions of the wardrobe's copying were less than that of the treasury. Finally, the cycle ended with the final wardrobe account roll, prepared for enrolment on the pipe rolls. Multiple membranes of the onus rolls, transferred and already shortened to several pages for entry into the wardrobe's final account book, were further condensed to just one single sentence in the final account roll. ${ }^{44}$

\footnotetext{
44 In the case of 29 Edward I (1300-1301), 33 pages of treasury receipts in the wardrobe book (London, The British Library, Add. Ms. 7966A, fol.1-18) were condensed to one sentence in the ready-to-enrol wardrobe account of the same year (Kew, TNA, E 101/360/25, m. 1: Idem reddit compotum de 29,031€ 16 s. 2 d. receptis de Thesauro regis ad Scaccarium, receptis de Waltero, Coventrensi et Lichesfeldensi episcopo, thesaurario et camerariis de Scaccario, per quatuor brevia de liberate hoc anno $29^{\circ}$. Scilicet per manus diversorum, sicut continet in libro de particulis prefati custodis et in libro predicti contrarotulatoris, inde in Thesauro liberantur, et etiam in pelle memorandorum dicte recepte de terminis sancti Michaelis et Pasche hoc anno 29 et termino sancti Michaelis anno $30^{\circ}$ incipit).
} 
The clerks of the wardrobe did not only copy and extract the onus rolls, but also used them by comparing payments made by the treasury with their own records. The left hand margins in the onus roll, drawn by the exchequer's scribe, bear testimony to this. An inspection reveals section and membrane sums, possibly introduced by the wardrobe's clerk to check the payments made by the treasury. ${ }^{45}$ The marginal notes also helped the wardrobe to track down payments in their own records. For that reason, most marginal notes reveal the name or function of a beneficiary ${ }^{46}$ as well as additional accounting information. ${ }^{47}$ The right margin, if apparent, was seldom used. ${ }^{48}$ At the end of the copying and checking process, the wardrobe's scribe marked the roll with a small note on the dorse or at the end of the roll. ${ }^{49} \mathrm{In}$ some cases, the scribe put down these notes in the middle of the roll or after a membrane. ${ }^{50}$ This shows that the copying and examining process was frequently not finished in one go but rather took several sessions. The small notes served as an indicator from where to continue the extraction process. The onus rolls were therefore more than just a vehicle of copying information from one record to another.

The onus rolls were used to transmit information from one branch of royal government (treasury) to the other (wardrobe), and as such were an intermediary form. They were not part of the audit of the wardrobe with the exchequer. ${ }^{51}$ They were not meant to be kept, as the final product of the audit-the pipe rolls-fulfilled that purpose.

45 Kew, TNA, E 101/355/9, m.1: Summa 3,260 £ 18 s. 5 d. [...] Summa 1,049 £ 9 s. [...] Summa a festo sancti Hillarii usque huc 2,007 £ $18 \mathrm{~s} .71 / 2 \mathrm{~d}$.

46 See e. g. Kew, TNA, E 101/366/24, m. 2a : De Bello Marisco [...] Clericus coquina [...] Ffriscobaldi [...] W' Regin [...] Sandale pro jocalia [...] Cofferus Londoniensis [...] Memorandum clericus marscalie [...] De Rokesle [...] Memorandum clericus marescalie [...] Sandale.

47 See e. g. Kew, TNA, E 101/366/24, m. 2a: Summa [...] Unde respondebitur [...] Non reparatur istium debitum de $10 £\left[\right.$ [...] De onere, quod in exitu per jornale [...] Memorandum de istius $2^{\text {bus }}$ summis.

48 In the case of the first onus roll, the scribes used the left margin only two times. Firstly, to add text, which had been forgotten during the copying process, and secondly, to mark the spot up to where the roll had been examined: Kew, TNA, E 101/355/9, m. 7: 3,021 £ 8s. 81/2 d. probatur, m. 8: examinatur usque huc. In a later onus roll, the scribe made use of the right margin for several annotations. Nevertheless, compared to the left margin, the right one was barely used: Kew, TNA, E 101/358/27, no.13, m. 1: Cancellavit, quod in anno 34to m. 2: Cancellavit, quod isto billa immunetur, E 101/358/27, no.11, m. 3: Quod intratur in titulo de dona anni presentis, [...] Claxton', m. 4: Usque huc.

49 See e. g. Kew, TNA, E 101/361/12, m. 27: Extractur per Bed'; E 101/366/14, m. 1': Intratur totum et examinatur; E 101/368/26, m. $1^{\mathrm{d}}$ : Examinatur totum et intratur.

50 See e.g. Kew, TNA, E 101/364/24, m. $1^{\mathrm{a}}$ : Examinatur; E 101/366/14, m. $2^{\mathrm{a}}$ : Extractur usque huc; E 101/366/24, m. 2a : Extractur usque huc.

51 That the onus rolls were not used during the wardrobe-exchequer audit can be derived from the entries of the receipt section of the final wardrobe account to be enrolled onto the pipe rolls. They state that the information about the payments came from the wardrobe's books and the issue roll of the treasury: Kew, TNA, E 101/364/14, m. 1: [...] sicut continuit in libro de particulis dicti custodis et in libro predicti contrarotulatoris, eidem Thesauro liberavit et etiam in pelle memorandorum dicte recepte de terminis sancti Michaelis et Pasche hoc anno 31 et termino sancti Michaelis anno 32 incipiente. 


\section{Why rolls?}

The choice of the roll form for the onus rolls ought to be explained with the practices of the institution in which they were produced: the exchequer. Since the twelfth century, it kept all of its accounts in the form of rolls. Scholarship has shown the impetus of the exchequer's bureaucratic routines. Within the royal administration, those routines were the main reason why other branches of government-such as the wardrobe, the chancery, and the judicial benches-adopted the roll for their record keeping. ${ }^{52}$ Furthermore, the practice of the royal administration was a model for other institutions, such as the English bishoprics. ${ }^{53}$

Even though bureaucratic routines are a convincing explanation for the dominance of the roll form in the administration of the kings of England, they do not explain why the roll was adopted in the first place. To add to this uncertainty, another question has to be raised, which stems from the administrative practices around the onus rolls: why did the wardrobe's scribes go off the 'well-trodden path' and start to use codices for some of their accounts?

Scholarship has offered a multitude of explanations for the choice of the roll form. The major problems with almost all of these explanations are firstly their monocausality and secondly their generalisation. Most researchers have tried to explain all facets of the roll's use with very few reasons. I scrutinize these common hypotheses and offer an alternative approach for the issues of form, content and function. In order to keep the argumentation streamlined, the only hypotheses discussed are the ones connected to England and its royal administration. The strongest claim suggests an intrinsic connection between the medium's content and its form. Some scholars have stressed that the roll was used in the Middle Ages almost exclusively for accounting and judicial records. ${ }^{54}$ A glance over Western European archives seem to support this hypothesis. Rolls were used throughout (Western) Europe for accounting from the twelfth to the fourteenth centuries..$^{55}$ Nevertheless, if one widens the view, it becomes evident that the roll form was not merely limited to accounting or even administrative record keeping in general, but can be found in almost every field of medieval literacy. ${ }^{56}$ Although scribes in very different contexts chose the roll as their medium of

52 For the development of the different roll groups and their similarities with each other, mainly from a semantic point of view, stressing the importance of routines, see Kypta 2014, 222-272. For the origin of the chancery rolls see the discussion between Vincent 2004 and Carpenter 1997, 2009. My PhD thesis will further investigate the importance of the exchequer for the spread of the rolls in England.

53 Vincent 1994.

54 Favier 1993, 831; Brown 2007, 180.

55 For Northern France and the Low Countries, see B. Lyon/Verhulst 1967; Lalou 2006. For the Empire, see Mersiowsky 2000, 84, 95-96. For the Iberian Peninsula, see Aragó 1979; Bisson 1984, 13.

56 See e. g. Studt 1995; Lalou 2006: "Le format du rouleau, le 'rotulus', a été utilisé au Moyen Âge à côté du codex ou registre pour recopier des actes, des chartes (ce sont les cartulaires en rouleau), pour recopier des armoriaux ou des arbres généalogiques, des documents judiciaires mais surtout des 
writing, one cannot deny that rolls were prominent in administrative record keeping. Since they were often inscribed with non-administrative texts, explaining a manuscripts' form solely by its content is insufficient. Instead, we have to turn away from the question of 'form and content' and move towards a 'functional' approach. The premise 'form follows function' enjoys great popularity not only among architects since the late-nineteenth century, but also among historians.

Firstly, we consider the production processes of the roll and codex, and whether the roll was 'easier', 'quicker', and 'cheaper' to create. One could argue that the overall perceived 'efficiency' and 'flexibility' of the roll's production process is a prominent reason for the use of rolls in the administration of the kings of England. Perhaps the roll is easier to expand in comparison to the codex and could be produced at a lower cost. Both arguments hold true for some cases, but not for others. Most administrative rolls were indeed cheaper to produce than codices with a wooden covering, which required the services of a professional bookbinder. There are no such codices in the wardrobe for accounting. All of the accounting books were limp-bound codices. Most of the more voluminous examples were bound outside the court by bookbinders, increasing costs. Even so, the administration could save money with the codex, as its pages were inscribed mostly on both sides, while the roll's membranes-if drawn up 'chancery style'-as a rule bore text on only one side. On the other hand, many if not most 'exchequer-style' rolls present text on both sides of its membranes. These examples already show the dilemma of finding a functional explanation for the choice of the roll: there are so many different styles of rolls and codices, ways of producing them, and also different contexts in which they were used, making it almost impossible to come to a valid generalisation.

Before diving into the depths of the argumentation for and against the roll's production advantages over the codex, it is worth noting that this hypothesis is one of the more valid ones. The production and inscribing process of rolls-independent of their form or format-did not require the planning that was necessary with a codex. At the core of this lies the quire structure. The scribe had to pay attention to when to stop adding double pages in the middle and instead to continue writing on the second half of the quire. Many codices bear witness to this problem, as they have single or double pages attached at the end of an otherwise regular quire. Therefore, constructing a codex was more difficult than a roll. Another advantage of the roll form was the wide use of parchment pieces in different shapes. Unlike for codices, all kinds of parchment 'leftover' pieces could still be used to form a roll. The roll was much easier to extend than a codex. This point holds only true for unbound books, and-very importantlyunbound 'exchequer-style' rolls. Once bound, the codex and the 'exchequer-style' roll

documents comptables, en grand nombre à partir du XIII ${ }^{\mathrm{e}}$ siècle. Il nous reste quelques exemplaires de rouleaux utilisés pour copier des textes littéraires, un évangile aux femmes, un ou deux rouleaux contenant des pièces lyriques, plusieurs chroniques universelles en rouleaux." 
had to be unbound in order to add membranes or pages at a certain point. ${ }^{57}$ As all the account books of Edward I's wardrobe were bound only after they had been inscribed, the problem of unbinding them for further extensions was not frequent. Therefore, this is a reasonable argument, even though it does not convince in all cases and for all types of records.

Some scholars opted for a possible advantage of the roll form in accounting, since the individual rotuli of the 'exchequer style' roll could have been written or copied by several scribes simultaneously, increasing the efficiency of the process. ${ }^{58}$ As much as this point is valid for the rolls of the exchequer, it also holds true for the codices. Because quires-as with the rotuli of the exchequer rolls that often linked to a certain ledger account or administrative unit-were inscribed and copied individually, allowing for multiple scribes to work on one codex. Therefore, several scribes could work on various membranes for a rotulus, as well as various quires for an eventual bound codex. Scribes working simultaneously were not a roll-related feature. ${ }^{59}$

The second part of the 'form follows function' premise leads to the use of the manuscripts. The only argument brought forward by scholarship for the choice of the roll is their portability. ${ }^{60}$ As with the production process, this generalisation cannot easily stand its ground against the plurality of sizes and types of documentation in the royal administration. The portability argument is twofold: firstly, weight and size, i. e. the materiality of the manuscripts; and secondly, transportation practices. While the former (material) reasons are mostly incorrect, the latter causes (transport practices) are valid. The assertion that the roll is more transportable than the codex rests on an odd comparison: frequently, scholars juxtapose small and medium sized rolls (w. $<250 \mathrm{~mm} \times 1 .<500 \mathrm{~mm}$ per membrane) with codices that bear heavy wooden bindings. Certainly, with these format specifications, rolls are easier to transport, as they are much lighter and more flexible than the codex. But again-as already seen with the argument for the roll's cheaper costs of production-this comparison is lame. Turning the argument around, large rolls could then be compared to small, limp-bound codices, leading to the result that codices are lighter and therefore easier to transport

57 The only advantage the 'exchequer style' roll had over a codex was that a rotulus could be added at the very end of the roll without unbinding it.

58 Clanchy $2013^{3}$, 143: “[...] the separate membranes of which they [rolls] were composed could be of slightly different sizes, and they could be compiled separately by different clerks and then stitched together in appropriate order [...]”. E. Lalou also suggest this point, while in the same sentence dismissing it again, see Lalou 2006: "Le Rouleau était peut-être plus facile à écrire simultanément par plusieurs personnes, encore qu'il fût possible, dans le cas d'un registre, de distribuer des cahiers à plusieurs scribes.”.

59 Most of the wardrobe books were bound after the individual quires had been inscribed. Therefore, multiple scribes could compile different quires, as most of the quires were structured around a specific ledger account.

60 For England, see Vincent 2004, 42, and in this volume. For rolls in general, see Studt 1995, 326, 328, 330-331, 336; Robinson 2008, 45; Skemer 2012, 72; Kössinger 2015, 164. 
than rolls. Since the accounting books of the wardrobe never bear heavy bindings and are instead limp bound, the whole justification about the disadvantage of the codex due to its weighty binding becomes obsolete. Furthermore, a 'chancery-style' roll of accounts, inscribed only on the recto side that bore the same amount of text as a limp bound codex, in which both the recto and verso were used, would be lighter, because less parchment was needed. Rolls were not per se anticipated as the more transportable medium. The very large 'exchequer-style' rolls, like the pipe and memoranda rolls, were not made to be very transportable. With a format of roughly $350 \mathrm{~mm}$ in width and 1,500 $\mathrm{mm}$ in length, even rolled up they do not serve as a transportable form. Those examples highlight that such sweeping explanations are meaningless.

Rather, it is important to look at the different functions that the documents served. A small codex (w. $<100 \mathrm{~mm} \times 1 .<200 \mathrm{~mm}$ ) could be as transportable as a small roll since practicality was the main goal. On the other hand, the large pipe rolls were the exact opposite of their small counterparts. A large wooden-bound cartulary is the opposite of a small limp bound codex-they represented the institution that produced them.

The way in which rolls and codices were kept and transported differs. The royal administration kept rolls usually in leather or hemp bags. We can derive this from the surviving pouches as well as from the records, e. g. inventory lists. ${ }^{61}$ Codices were never stored in bags or pouches. They found their way directly into leather or wooden forcers and coffers, which were then placed in larger wooden chests. The chests and some of the forcers and coffers were fitted with multiple locks to secure their content. Evidence of this practice is found from the written records and the few surviving chests from the thirteenth and early fourteenth century. ${ }^{62}$ When transferred into longterm storage, the rolls were also placed in these chests, as were other administrative and diplomatic documents of value. What is striking is that the medieval contemporaries did not associate the administrative codices with the idea of easy transportation. Small format codices are very rare in the English administration in the thirteenth century. Medium or large codices dominate. On the other side, rolls survive in a greater variety of formats and sizes as codices, with many being very small and trans-

61 For a surviving pouch see e. g. Kew, TNA, E 199/96/1, front title: Bedford' et Buck' de anno regni regis Edwardi [...; lost text]. For an inventory with rolls e. g. Kew, TNA, E 101/337/21, no. 2: [...] In 1 pucha compotum Samps' de Gretham de manerio de Sabrichtesworth anno $22^{\circ}$. Item 1 alba bursa de corio particule compotum Johannis, filii Thome, et Unifr' de Waled' Dunsterr' de exito Insule Verte anno $22^{\circ}$ [...].

62 Most of the chests are help today under the reference: Kew, TNA, E 27 (e. g. E 27/3: oak chest with three locks, reinforced with iron plates; w. $1,670 \mathrm{~mm} \times 1.770 \mathrm{~mm} \times \mathrm{h} .920 \mathrm{~mm}$; c.1255). Many of the chests were at the former Museum of the Public Record Office in Chancery Lane (see Maxwell-Lyte $\left.1926^{12}, 71-72\right)$. Today, only two or three such chests are exhibited in the Museum of The National Archives at Kew. For inventories with codices in chests, see e. g. London, BL, Add. Ms. 7966A, fol. 39v Reparatio coffrorum: Domino Johanni de Langeford pro reperatio coffrorum cum librum Garderobe, ut in serruris, bendis, ferris et aliis per eiusdem coffrum neccesariis per manus proprias apud Lincoln', $14^{\circ}$ die februariis-20d. 
portable. The use of bags for protection and storage as well as easy transportation is another indicator for the contemporaries' association in royal administration: the roll was the more portable of the two book forms. In theory, rolls did not offer much of an advantage for transportation, nonetheless, in practice, it seems as the medieval contemporaries connected an idea of transportability with most rolls-not with all, as we have seen with the large rolls series. Eventually, the scholarship's argument for an easier transportation of the roll versus the codex has to be partly acknowledged for the administration of medieval England-not from a theoretical point of view but from a practical one.

French-speaking scholars have discussed the 'life-span' of writing. ${ }^{63}$ Two aspects of this idea are worth following up. Firstly, how long the documents were in active use, and secondly, how frequently they were consulted during their life. Many of the wardrobe's account books were used over the course of multiple years. Some of them, most prominently the credit and debt books, were consulted up to two decades after their initial compilation. The same holds true for many of the exchequer's codices. Those records with 'handbook character', i. e. documents that had to be consulted regularly, were not written onto rolls but rather into codices. The best examples for this type are the Red and Black Book of the Exchequer as well as the Domesday Book and its abbreviations, and finally the Books of Fees. ${ }^{64}$ Both exchequer and wardrobe clerks referred to rolls for records that had a short life span-e. g. such that served as preliminary documentation-or were not consulted frequently. An exemption from this rule seem to be the pipe rolls. Even though they were only written down for the sake of accountability with the sheriffs and other officials for a specific year, the pipe roll's importance was to enable the exchequer to keep track of unsettled payments. Therefore, the pipe rolls were consulted over a long period (up to two or three decades). ${ }^{65}$ Nevertheless, in comparison to most of the codices of the exchequer, they did not serve as 'handbooks'.

Consultation is key for the understanding of the codex. One has to be cautious, however, as consultation practices were not limited to the codex form. The 'exchequer style' rolls offered much of the same easy access and consultation as did codices. ${ }^{66}$ This might have been one of the crucial factors why the exchequer did not introduce codices and kept continuing writing down its accounts on rolls. For consultation purposes, the exchequer-style rolls were sufficient. The wardrobe never used 'exchequer-style' rolls. Instead, they fell back on the codex for their frequently consulted

\footnotetext{
63 See Bertrand 2015, 29-78 ("La vie des écrits": "Longue durée” and “Temps court”).

64 For editions, see Liber niger Scaccarij, nec non Wilhelmi Worcestrii annals Rerum Anglicarum, cum preafatione et appendice Thomae Hearnii ad editionem primam Oxoniae editam, ed. Hearne; The Red Book of the Exchequer, ed. Hall; Liber feodorum, ed. Maxwell-Lyte; Domesday Book, ed. Morris (an updated and corrected online version of this edition can be found on http://www.domesdaybook.net/ [last accessed: 23.8.18]).

65 See Cassidy 2012; Giele/Peltzer/Trede 2015, 690-691.

66 Clanchy $2013^{3}, 142$. See also Cassidy and Vincent in this volume.
} 
accounts. Scholarship has offered an explanation for their different choice of form: Italians. ${ }^{67}$ Never before did an English king rely so intensively on Italian credits as did Edward I for his wars in Wales, Scotland, and on the Continent. ${ }^{68}$ Since the early thirteenth century, Italian bookkeeping with its many long-term cash and credit transactions relied heavily on the codex. ${ }^{69}$ The intensified connection of Italian merchantsin particular the Ricciardi of Lucca from the 1270s to mid-1290s and the Frescobaldi of Tuscany in the late 1290s and 1300s-to Edward I can be seen as one of the main reasons for the introduction of the codex in the bookkeeping practices of the wardrobe.

One final aspect closely related to routines: institutional identity. The onus rolls and their record context present this idea at its best. The bookkeeping of the English exchequer was inseparably linked with its rolls; primarily its 'exchequer-style' pipe rolls. Consequently, when sending the wardrobe information about payments made on its behalf, the exchequer's clerks would routinely use the roll. At the wardrobe, at least from the 1290s, under the leadership of Walter Langton and John Droxford, the routine of presenting multiple rolls at the regular audit with the exchequer was abandoned. Instead, the keeper and controller presented mainly codices. For that purpose, the clerks had to copy the content of the onus rolls into the final wardrobe book. Using codices was a new and defining moment for the wardrobe, and symbolized its great significance as a financial institution. Much debate in scholarship has focused on the institutional independence (or not) of the wardrobe, precisely during this period, the 1290s. Recent scholarship is right in stressing that the exchequer and the wardrobe should not be separated so much, as they worked closely together to serve the same purpose: providing the king with monetary resources. ${ }^{70}$ The materiality, in particular the form of the surviving documents, supports the older scholarship's idea of a rivalry between the two branches. ${ }^{71}$ The wardrobe became so influential that its officials wanted to set it apart from the ever so strong routines of the exchequer. At the end, both viewpoints do not exclude each other but rather have to be taken together: there was a 'rivalry' between the two institutions showing itself in an institutional identity while at the same time both branches did work closely together.

By analysing the onus rolls, we can get a glimpse of the practices and routines of English financial administration under Edward I. Those practices and routines are key to understand why a certain form of documentation was adopted. Both institutions

67 This theory has been brought forward by Prestwich 1997, 96. My PhD thesis further investigates the reasons and implications for the introduction of the codex in the wardrobe under Edward I.

68 For the credit relationships of Edward I with Italian bankers C. Johnson 1903; Whitwell 1903; Goldthwaite 1973; Kaeuper 1973a, 1973b, 1973c; Prestwich 1979; Del Punta 2002; Accounts of the English Crown with Italian Merchant Societies, 1272-1345, eds. Bell, Brooks and Moore; Bell/Brooks/Moore 2011.

69 Santini 1877; Castellani 1958; Lee 1972, 1973a, 1973b; Arlinghaus 2004, 2006.

70 See for this standpoint in particular Barratt 2004, 2005.

71 For this earlier standpoint, see in particular Tout 1920-1933, vol. 2. Following him e. g. B. Lyon/M. Lyon/Lucas 1983, xxxi, xxxxix-xl. 
had their routines: for the exchequer it was the unlimited use of the roll for bookkeeping, for the wardrobe, the roll for the daily and preliminary accounting and the book for the final accounts. The choice of a particular form of record keeping relies on a multitude of factors. Firstly, it was slightly easier to produce a 'chancery-style' roll like the onus roll than a codex. Secondly, portability was a factor for the medieval officers and scribes, even though in theory, the roll did not offer any advantages over the codex. Small and medium sized rolls, such as the onus roll, were somehow associated with transportability. As the onus rolls were transported from the exchequer to the wardrobe, the association with portability played a part in the choice of the roll form. Thirdly, most of the codices were used as the form of long-term storage and repeated access. On the other hand, most rolls-a notable exception being the pipe rolls-were connected with short-term information storage. Lastly, the choice of a particular form was deeply rooted in the institution's routine. The exchequer recorded all its accounts on rolls-hence the choice of the roll form for the onus rolls. Furthermore, a medium's form can be interpreted as a sign of institutional identity: the exchequer's use of its special 'codex-like' rolls and the wardrobe's refuse of adopting this system but rather introducing a new form with the codex bear witness to this.

Even though the wardrobe began to use books in the late thirteenth century, rolls remained the main medium of the administrative literacy after 1300. In fact, books very much remained a medium of the wardrobe and later the chamber until the end of the Middle Ages. The routine of keeping rolls was so strong that for most records it remained unchallenged until the early modern period. Rolls were the symbol not only of the exchequer but also of royal administration itself. 


\section{Appendix}

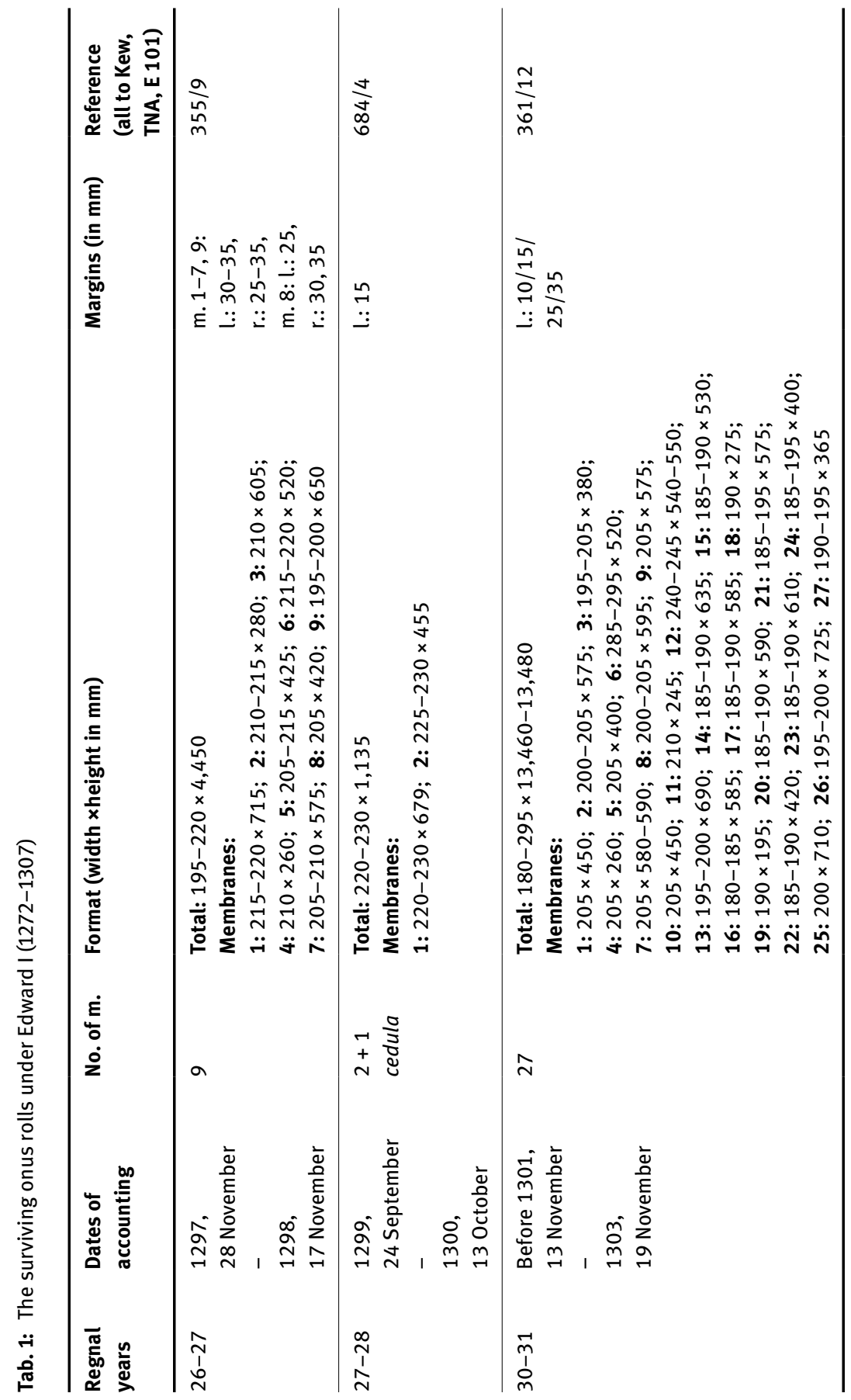




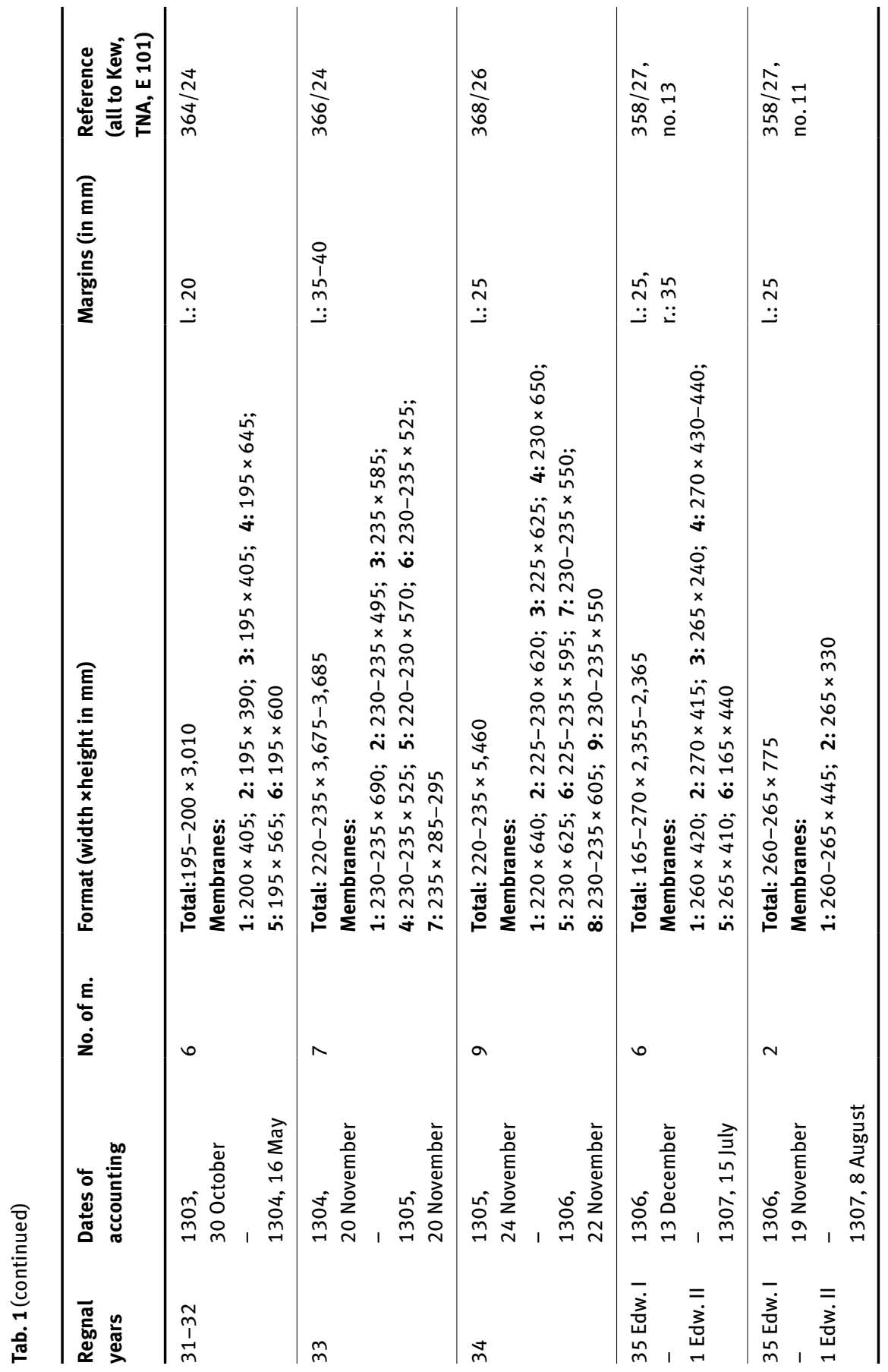




\section{Manuscripts}

\section{Kew, The National Archives (TNA)}

Chancery: Chancery Miscellanea:

$$
\begin{aligned}
& \text { C 47/3/51/10 } \\
& \text { C 47/35/15 }
\end{aligned}
$$

Chancery: Liberate Rolls:

$$
\text { C } 62 / 77
$$

Chancery: Warrants for the Great Seal, Series I:

$$
\begin{aligned}
& \text { C 81/1328/18 } \\
& \text { C 81/1668/11 } \\
& \text { C 81/1684A/47 }
\end{aligned}
$$

Exchequer: Treasury of Receipt: Chests:

$$
\text { E } 27 / 3
$$

Exchequer: King's Remembrancer: Accounts Various:

$$
\begin{aligned}
& \text { E 101/11/20 } \\
& \text { E 101/337/21 } \\
& \text { E 101/351/10 } \\
& \text { E 101/355/9 } \\
& \text { E 101/357/11 } \\
& \text { E 101/358/27 } \\
& \text { E 101/360/25 } \\
& \text { E 101/361/12 } \\
& \text { E 101/364/14 } \\
& \text { E 101/364/24 } \\
& \text { E 101/366/24 } \\
& \text { E 101/368/26 } \\
& \text { E 101/369/11 } \\
& \text { E 101/684/4 }
\end{aligned}
$$

Exchequer: King's Remembrancer and Lord Treasurer's Remembrancer: Sheriffs' Accounts,

Petitions, etc.:

E 199/96/1

Exchequer: Exchequer of Receipt: Receipt Rolls and Registers:

E 401/151

E 401/153

Exchequer: Exchequer of Receipt: Issue Rolls and Registers:

$$
\begin{aligned}
& \text { E 403/111 } \\
& \text { E 403/113 } \\
& \text { E 403/1280 }
\end{aligned}
$$

London, The British Library (BL)

Additional Manuscripts:

Add. Ms. 7966A

Add. Ms. 37655

Manchester, John Rylands Library (JRL)

Latin Manuscripts:

Lat. Ms. 230 


\section{Printed sources}

Accounts of the English Crown with Italian Merchant Societies, 1272-1345, eds. Adrian R. Bell, Chris Brooks and Tony K. Moore (List and Index Society 331), Chippenham 2009.

Domesday Book: A Survey of the Counties of England, ed. John E. Morris (History from the Sources), 35 vols. in 38, Chichester 1975-1986.

Liber feodorum: The Book of Fees Commonly Called Testa de Nevill. Reformed from the Earliest MSS by the Deputy Keeper of the Records, ed. Henry Charles Maxwell-Lyte, 3 vols., London 19201931.

Liber niger Scaccarij, nec non Wilhelmi Worcestrii annals Rerum Anglicarum, cum preafatione et appendice Thomae Hearnii ad editionem primam Oxoniae editam, ed. Thomas Hearne, 2 vols., London $1744^{2}$.

Liber quotidianus contrarotulatoris garderobae. Anno regni regis Edwardi primi vicesimo octavo.

A. D.MCCXCIX \& MCCC: Ex codice Ms. in bibliotheca sua asservato typis edidit Soc. Antiq. Londinensis, ed. John Topham, London 1787.

Records of the Wardrobe and Household: 1285-1286, eds. Benjamin F. Byerly and Catherine R. Byerly, London 1977.

Records of the Wardrobe and Household: 1286-1289, eds. Benjamin F. Byerly and Catherine R. Byerly, London 1986.

The Court and Household of Eleanor of Castile in 1290: An Edition of British Library, Additional Manuscript 35294 with Introduction and Notes, ed. John Carmi Parsons (Studies and Texts 37), Toronto 1977.

The Red Book of the Exchequer, ed. Hubert Hall, 3 vols., London 1896.

The Wardrobe Book of 1296-1297: A Financial and Logistical Record of Edward l's 1297 Autumn Campaign in Flanders against Philip IV of France, eds. Bryce Dale Lyon and Mary Lyon (Commission royale d'histoire. Publications in-octavo), Brussels 2004.

\section{Bibliography}

Aragó, Antonio M. (1979), “'Folium', 'rotulus’ y ‘liber’ en la documentación Catalano-Aragonesa (s. XI-XIII)", in: Palaeographica, diplomatica et archivistica: Studi in onore di Giuilio Battelli (Storia e letteratura. Raccolta di studi e testi 139-140), 2 vols., Rome, vol.1, 295-303.

Arlinghaus, Franz-Josef (2004) “Bookkeeping, Double-Entry Bookkeeping”, in: Christopher Kleinhenz (ed.), Medieval Italy: An Encyclopedia (The Routledge Encyclopedias of the Middle Ages 9), 2 vols., New York, vol.1, 147-150.

Arlinghaus, Franz-Josef (2006), “Account Books”, in: Franz-Josef Arlinghaus (ed.), Transforming the Medieval World: Uses of Pragmatic Literacy in the Middle Ages (Utrecht Studies in Medieval Literacy 6), Turnhout, 43-69.

Calendar of Documents Relating to Scotland Preserved in her Majesty's Public Record Office, London (1881-1888), ed. Jospeh Bain, 5 vols. Edinburgh.

List of Documents Relating to the Household and Wardrobe: John to Edward I (1964), compiled with the assistance of P. M. Barnes (Public Record Office Handbooks 7), London.

Barratt, Nicholas D. (2004), "Finance on a Shoestring: The Exchequer in the Thirteenth Century", in: Adrian Jobson (ed.), English Government in the Thirteenth Century, Woodbridge, 71-86. 
Barratt, Nicholas D. (2005), "Counting the Cost: The Financial Implications of the Loss of Normandy", in: Richard H. Britnell, Robert Frame and Michael C. Prestwich (eds.), Thirteenth Century England X: Proceedings of the Durham Conference 2003, Woodbridge, 31-40.

Bell, Adrian R./Brooks, Chris/Moore, Tony K. (2011), "Credit Finance in Thirteenth-Century England: The Ricciardi of Lucca and Edward I, 1272-94", in: Janet Burton, Frédérique S. J. Lachaud, Phillipp R. Schofield, Karen Stöber and Björn Weiler (eds.), Thirteenth century England XIII: Proceedings of the Paris conference 2009, Woodbridge, 101-116.

Bisson, Thomas N. (1984), "Introduction", in: Fiscal Accounts of Catalonia under the Early CountKings (1151-1213), 2 vols., Berkeley/Los Angeles/London, vol.1, 3-323.

Brown, Michelle P. (2007), “The Triumph of the Codex: The Manuscript Book before 1100”, in: Jonathan Rose and Simon Eliot (eds.), A Companion to the History of the Book (Blackwell Companions to Literature and Culture 48), Malden, 177-193.

Byerly, Benjamin Franklin/Byerly, Catherine Ridder (1977), “Introduction”, in: Records of the Wardrobe and Household: 1285-1286, eds. Benjamin F. Byerly and Catherine R. Byerly, London, ix-xlvi.

Byerly, Benjamin Franklin/Byerly, Catherine Ridder (1986), “Introduction”, in: Records of the Wardrobe and Household: 1286-1289, eds. Benjamin F. Byerly and Catherine R. Byerly, London, $\mathrm{i}-\mathrm{xxx}$.

Cárcel Ortí, Maria Milagros (ed.) (1997²), Vocabulaire international de la diplomatique (Col-lecció oberta 28), Valencia.

Carpenter, David A. (1997), “The English Royal Chancery in the Thirteenth Century”, in: Kouky Fianu (ed.), Ecrit et pouvoir dans les chancelleries médiévales: espace français, espace anglais. Actes du colloque international de Montréal, 7-9 septembre 1995 (Textes et études du moyen âge 6). Louvain, 25-53.

Carpenter, David A. (2009) “'In testimonium factorum brevium': The Beginnings of the English Chancery Rolls", in: Nicholas C. Vincent (ed.), Records, Administration, and Aristocratic Society in the Anglo-Norman Realm: Papers Commemorating the 800th Anniversary of King John's Loss of Normandy, Woodbridge, 1-28.

Castellani, Arrigo Ettore (1958), "Frammenti d'un libro di conti di banchieri fiorentini del 1211", in: Studi di filologia italiana 16, 19-96.

Del Punta, Ignazio (2002) "Il falliamento della compagnia Ricciardi alla fine del secolo XIII: un caso essemplare?", in: Archivo Storico Italiano 592 (2), 221-268.

Dryburgh, Paul (2015), "The Form and Function of the Originalia Rolls", in: David Crook and Louise J. Wilkinson (eds.), The Growth of Royal Government under Henry III, Woodbridge, 30-43.

Dryburgh, Paul (s. d.), "Originalia Rolls”, <http://www.finerollshenry3.org.uk/content/commentary/ originalia.html> (last accessed: 18.12.2015).

Favier, Jean (1993), “Rôle”, in: Jean Favier (ed.), Dictionnaire de la France médiévale, Paris, 831. Giele, Enno/Peltzer, Jörg, with the collaboration of Trede, Melanie C. (2015). "Rollen, Blättern und (Ent)Falten", in: Thomas Meier, Michael R. Ott and Rebecca Sauer (eds.), Materiale Textkulturen: Konzepte - Materialien - Praktiken (Materiale Textkulturen 1), Berlin/Boston/Munich, 677-693.

Goldthwaite, Richard A. (1973), "Italian Bankers in Medieval England”, in: Journal of European Economic History 3, 763-72.

Guyotjeannin, Olivier/Vielliard, Françoise (eds.) $\left(2014^{2}\right)$, Conseils pour l'édition des textes médiévaux: Conseils généraux (Orientations et méthodes 27), Paris.

Johnson, Charles (1903), "An Italian Financial House in the 14th century”, in: Transactions St Albans and Hertfordshire Architectural and Archaeological Society, new ser. 1, 320-334.

Johnson, Charles (1923), "The System of Account in the Wardrobe of Edward I", in: Transactions of the Royal Historical Society 6, 50-72.

Johnson, John Henry (1929), “The System of Account in the Wardrobe of Edward II", in: Transactions of the Royal Historical Society 12, 75-104. 
Kaeuper, Richard William (1973a), Bankers to the Crown: The Riccardi of Lucca and Edward I., Princeton.

Kaeuper, Richard William (1973b), “The Frescobaldi of Florence and the English Crown”, in: Studies in Medieval and Renaissance History 10, 41-95.

Kaeuper, Richard William (1973c), "The Role of Italian Financiers in the Edwardian Conquest of Wales”, in: Welsh History Review 6 (4), 387-403.

Kössinger, Norbert (2015), “Gerollte Schrift: Mittelalterliche Texte auf Rotuli”, in: Annette Kehnel and Diamantis Panagiotopoulos (eds.), Schriftträger-Textträger: Zur materialmen Präsenz des Geschriebenen in frühen Gesellschaften (Materiale Textkulturen 6), Berlin/Boston/Munich, 151-168.

Kypta, Ulla (2014), Die Autonomie der Routine: Wie im 12. Jahrhundert das englische Schatzamt entstand (Historische Semantik 21), Göttingen.

Lalou, Élisabeth (2006), “Les rouleaux de comptes sur parchemin en France et en Angleterre (XIIIe_ XIVe siècles)”, <http://aedilis.irht.cnrs.fr/materiaux/21.htm> (last accessed: 2.5.16).

Lee, Geoffrey Alan (1972), “The Oldest European Account Book: A Florentine Bank Ledger of 1211”, in: Nottingham Medieval Studies 16, 28-60.

Lee, Geoffrey Alan (1973a), “The Development of Italian Bookkeeping 1211-1300”, in: Abacus 9 (2), 137-156.

Lee, Geoffrey Alan (1973b), “The Florentine Bank Ledger Fragments of 1211: Some New Insights”, in: Journal of Accounting Research 11 (1), 47-61.

Lyon, Bryce Dale/Verhulst, Adriaan E. (1967), Medieval Finance: A Comparison of Financial Institutions in Northwestern Europe (Werken uitgegeven door de Faculteit van de Letteren en Wijsbegeerte 143), Bruges.

Lyon, Mary/Lyon, Bryce Dale/Lucas, Henry S. (1983), “Introduction”, in: The Wardrobe Book of William de Norwell: 12 July 1338 to 27 May 1340, eds. Mary Lyon, Bryce Lyon and Henry S. Lucas, with the collaboration of Jean de Sturler (Commission royale d'histoire. Publications in-octavo), Brussels, xi-cxxiii.

Maxwell-Lyte, Henry Churchill (1926 $\left.{ }^{12}\right)$, Catalogue of Manuscripts and other Objects in the Museum of the Public Record Office with Brief Descriptive and Historical Notes, London.

Mersiowsky, Mark (2000), Die Anfänge territorialer Rechnungslegung im deutschen Nordwesten: Spätmittelalterliche Rechnungen, Verwaltungspraxis, Hof und Territorium (Residenzenforschung 9), Stuttgart.

Mersiowsky, Mark (2007), “Rechnungen”, in: Werner Paravicini (ed.), with the collaboration of Jan Hirschbiegel and Jörg Wettlaufer, Höfe und Residenzen im spätmittelalterlichen Reich: Hof und Schrift (Residenzenforschung 15,3), Ostfildern, 531-551.

Prestwich, Michael C. (1979), “Italian Merchants in Late Thirteenth and Early Fourteenth Century England", in: The Dawn of Modern Banking (Publications of the Center for Medieval and Renaissance Studies), New Haven, 77-104.

Prestwich, Michael C. (1988), Edward I (English Monarchs), London.

Prestwich, Michael C. (1997), “English Government Records, 1250-1330”, in: Richard H. Britnell (ed.), Pragmatic Literacy: East and West, 1200-1300, Woodbridge, 95-106.

Ramsay, Nigel (2008), “Archive Books”, in: John Barnard, Donald F. McKenzie, David McKitterick and Ian R. Willson (eds.), The Cambridge History of the Book in Britain, 6 vols., Cambridge, vol. 2, 416-445.

Robinson, Pamela R. (2008), “The Format of Books: Books, Booklets and Rolls”, in: John Barnard, Donald F. McKenzie, David McKitterick and Ian R. Willson (eds.), The Cambridge History of the Book in Britain, 6 vols., Cambridge, vol. 2, 41-54.

Sabapathy, John (2014), Officers and Accountability in Medieval England: 1170-1300, 0xford. Santini, Pietro (1877), "Frammenti di un libro di banchieri fiorentini scritto in volgare nel 1211", in: Giornale storico della letteratura italia 10 (28-29), 161-177. 
Skemer, Don (2012), “FraterRichard Bury's Roll: Ownership and Use of an Early Genealogical Chronicle of the Kings of England", in: Orietta Da Rols and Anthony S. G. Edwards (eds.), English Manuscripts before 1400 (English Manuscripts Studies 1100-1700 17), London, 60-106.

Steel, Anthony B. (1929), "The Present State of Studies on the English Exchequer in the Middle Ages", in: The American Historical Review 34 (3), 485-512.

Studt, Brirgit (1995), “Gebrauchsformen mittelalterlicher Rotuli: Das Wort auf dem Weg zur Schrift die Schrift auf dem Weg zum Bild”, in: Ellen Widder, Mark Mersiowsky and Peter Johanek (eds.), Vestigia Monasteriensia: Westfalen - Rheinland - Niederlande (Studien zur Regionalgeschichte 5), Bielefeld, 325-350.

Tout, Thomas Frederick (1920-1933), Chapters in the Administrative History of Medieval England: The Wardrobe, the Chamber and the Small Seals (Publications of the University of Manchester 126-127, 183-184, 207, 224/Historical ser. 34-35, 48-49, 57, 64), 6 vols., Manchester.

Vincent, Nicholas C. (1994), "The Origins of the Winchester Pipe Rolls", in: Archives 21 (91), 25-42. Vincent, Nicholas C. (2004), "Why 1199? Bureaucracy and Enrolment under John and his Contemporaries”, in: Adrian Jobson (ed.), English Government in the Thirteenth Century, Woodbridge, $17-48$.

Whitwell, Robert Jowitt (1903), "Italian Bankers and the English Crown”, in: Transactions of the Royal Historical Society 17, 175-233.

Wild, Benjamin L. (2012), “Introduction”, In: The Wardrobe Accounts of Henry III, ed. Benjamin L. Wild (The Publications of the Pipe Roll Society, new ser. 58), Loughborough, xi-clxxxvi.

Young, Charles George (1840), "Extracts from the Liberate Rolls, Relative to Loans Supplied by Italian Merchants to the Kings of England, in the 13th and 14th Centuries”, in: Archaeologia 28, 207-326.

\section{Websites}

Hull Domesday Project, <http://www.domesdaybook.net/> (last accessed: 23.8.18). 